\title{
Response of simple grass-white clover and multi-species pastures to gibberellic acid or nitrogen fertiliser in autumn
}

\author{
M. H. VAN ROSSUM, R.H. BRYANT, and G.R. EDWARDS \\ Faculty of Agriculture and Life Sciences, Lincoln University, PO Box 85084, Lincoln
}

Moniek.Vanrossum@lincolnuni.ac.nz

\begin{abstract}
Herbage dry matter (DM) production, botanical composition and nutritive value of pastures were measured in response to the application of $24 \mathrm{~g} /$ ha gibberellic acid (GA; $60 \mathrm{~g}$ ProGibb $\left.{ }^{\circledR} / \mathrm{ha}\right)$ and $50 \mathrm{~kg} \mathrm{~N} / \mathrm{ha}$ nitrogen fertiliser (N; $106 \mathrm{~kg}$ urea/ha) in autumn. Responses were compared for simple two species grass (perennial ryegrass or tall fescue)-white clover pastures and multi-species pastures where herbs (chicory and plantain), legumes (red clover and lucerne) and prairie grass were sown with the simple mixtures. Four weeks after application, the increase in DM yield averaged across pasture mixtures relative to untreated plots was 273, 104, and $493 \mathrm{~kg} \mathrm{DM} / \mathrm{ha}$ for GA alone, $\mathrm{N}$ fertiliser alone, and GA and $\mathrm{N}$ combined, respectively. Application of GA increased the white clover percentage in all pastures except simple tall fescue pastures. The percentage of herbs in multispecies pastures was increased by application of $\mathrm{N}$ but not GA. Crude protein concentration was decreased by GA application in all pastures except simple ryegrass pastures. The results from this study show that it is important to consider the botanical composition of pastures when determining the effect of GA on DM yield and nutritive value.
\end{abstract}

Keywords: crude protein, Cichorium intybus, Festuca arundinacea, gibberellins, Lolium perenne, Plantago lanceolata, nutritive value

\section{Introduction}

Pastoral farming in New Zealand is driven by seasonal feed supply and demand, and the amount of pasture that is grown on farm. In dairy herds, cows are required to sustain a high level of milk production over a long lactation. Lactation length is influenced by feed supply and extra days in milk in the autumn increases total milk yield. To increase pasture production in autumn, farmers often apply nitrogen $(\mathrm{N})$, but this can have adverse environmental impacts due to losses of $\mathrm{N}$ from urine via leaching from pasture (Di \& Cameron 2002). The problem is exacerbated as cooler temperatures reduce plant growth and $\mathrm{N}$ concentration of herbage accumulates. As animal demand for protein declines, the proportion of $\mathrm{N}$ excreted in urine increases, and urine deposited in autumn is subject to greater leaching losses due to high winter drainage (De Klein 2001; Di \& Cameron 2002).

Increasing public and government pressure to reduce $\mathrm{N}$ leaching has prompted investigations into alternative fertilisers and pasture species which can lead to increased dry matter production of pastures with reduced herbage $\mathrm{N}$ concentrations. Recent comparisons of simple perennial ryegrass-white clover and tall-fescue-white clover pastures with multi-species pastures (MSP) containing additional herbs and legumes, have shown greater annual dry matter (DM) yield (Nobilly et al. 2013) and reduced urine $\mathrm{N}$ excretion from dairy cows (Totty et al.2013) with MSP. The plant growth hormone, gibberellic acid (GA), may also present an opportunity to increase pasture production when pasture growth is limited (Matthew et al. 2009) and could be used as an alternative to $\mathrm{N}$ fertilisers in spring and autumn. A review of plant growth responses to GA showed that the median response to GA was $500 \mathrm{~kg} \mathrm{DM} /$ ha when applied once with rates between 25 and $700 \mathrm{~g}$ active ingredient/ha (Matthew et al. 2009). However, there is limited published information (Morgan \& Mees 1958; Scott 1959) available on the effects of GA applied at low rates on pasture production in autumn, and none on how it might affect DM yield response and botanical composition of multi-species pastures. The objectives of this study were to compare the effects of GA and $\mathrm{N}$ application on DM production and nutritive value of simple and MSP in autumn.

\section{Materials and Methods}

\section{Experimental site and design}

The experiment took place on the Lincoln University Research Dairy farm in Canterbury, New Zealand $\left(43^{\circ} 38^{\prime} \mathrm{S}, 172^{\circ} 27^{\prime} \mathrm{E}\right)$ between 23 March and 26 April 2011. The soil at the site is a Paparua sandy loam. Soil tests taken before the experiment began showed: $\mathrm{pH}=$ 5.8, Olsen $\mathrm{P}=33 \mathrm{mg} / \mathrm{L}, \mathrm{K}=0.38 \mathrm{me} / 100 \mathrm{~g}, \mathrm{Ca}=6.4$ $\mathrm{me} / 100 \mathrm{~g}, \mathrm{Mg}=0.46 \mathrm{me} / 100 \mathrm{~g}$ and $\mathrm{S}=0.16 \mathrm{me} / 100$ g. The pasture was sown in February 2010 and at the time of the experiment was 13 months old. The experimental area was under full irrigation and had previously been rotationally grazed by dairy cows. The experiment was a split plot factorial design laid out in three randomised blocks. The main plots were factorial 
combinations of two base grasses (ryegrass (RG) or tall fescue (TF)) and two levels of diversity (simple (base pasture plus clover), and base pasture plus herbs and legumes (MSP). Table 1 shows the plant species and cultivars in the main plot treatments. The four sub-plot factor combinations were: control (CNT, no GA or N); GA (24 g GA/ha); N (50 kg N/ha); and GA + N (24 g $\mathrm{GA} / \mathrm{ha}+50 \mathrm{~kg} \mathrm{~N} / \mathrm{ha}$ ). Nitrogen was applied in the form of urea $(47 \% \mathrm{~N})$ and granules were applied by hand. Gibberellic acid was applied by spray applicator using ProGibb-SG ${ }^{T M}(40 \% \mathrm{GA})$ and a surfactant $\left(\right.$ Contact $\left.^{T M}\right)$, both from NuFarm Ltd.

Gibberellic acid was applied at a higher rate than the manufacturers recommendation of $8 \mathrm{~g} \mathrm{GA} / \mathrm{ha}$ as a result of slower application speed than that used during sprayer calibration. The higher rate of $24 \mathrm{~g} \mathrm{GA} / \mathrm{ha}$ was consistent for all plots.

Experimental areas were situated within a larger grazing trial consisting of three 0.5 ha paddocks of each of the four pasture treatments (see Nobilly et al. (2013) for site description). Electric polywire was used to separate a $10 \times 10 \mathrm{~m}$ experimental area within each 0.5 ha paddock. On 23 March 2011, the experimental area was mown to $4 \mathrm{~cm}$ stubble height and the four subplot areas of $2 \times 8 \mathrm{~m}$ were marked out with wooden pegs. Fertiliser treatments were randomly allocated to sub-plots and were applied within 48 hours of mowing. Plots were allowed to regrow until final harvest four weeks later on 26 April 2011.

\section{Pasture measurements}

Dry matter yield at the end of the 4 week regrowth period was determined from one $0.4 \times 8 \mathrm{~m}$ cut taken with a rotary mower to $4 \mathrm{~cm}$ above ground level. The fresh weight $(\mathrm{FW})$ of herbage was recorded and a subsample of approximately $100 \mathrm{~g} \mathrm{FW}$ from each plot was taken to determine DM\%.

Snip samples of vegetation were taken from each plot at $4 \mathrm{~cm}$ height and two sub-samples (200g FW) were removed. One sample was freeze dried and ground through a $1 \mathrm{~mm}$ sieve prior to analysis using near infrared spectroscopyto measure the concentration of crude protein $(\mathrm{CP})$, organic matter $(\mathrm{OM})$, water-soluble carbohydrate (WSC), acid detergent fibre (ADF) and neutral detergent fibre (NDF) by the Lincoln University Analytical Laboratory. Metabolisable energy content was calculated using the modified $\mathrm{ADF}$ equation for forages (CSIRO 2007). A second sample was sorted into species and dead material, oven-dried at $65^{\circ} \mathrm{C}$, and percentage botanical composition on a DM basis was determined.

\section{Statistical analysis}

In week three of the regrowth period, cows broke the fence and grazed three of the four plots in one of the simple RG blocks. The three affected plots were treated as missing values in the analysis. Herbage DM yield, nutritive value and botanical composition at final harvest were analysed using ANOVA of a split plot design using Genstat (v. 12.2). Main plot factors were base grass $\times$ diversity and sub-plot factors were the GA $\times \mathrm{N}$ applications. Analysis of botanical composition of herbs, legumes other than white clover and prairie grass were performed for MSP treatments only.

\section{Results}

\section{Rainfall and temperature}

The maximum temperatures for the experimental period ranged from 10.4 to $24.8^{\circ} \mathrm{C}$ (mean $16.9^{\circ} \mathrm{C}$ ) and minimum temperatures ranged between 3.4 and $13.2^{\circ} \mathrm{C}$ (mean $7.8^{\circ} \mathrm{C}$ ). Mean soil temperature at $10 \mathrm{~cm}$ was $11.1^{\circ} \mathrm{C}$. Over the regrowth period the accumulated rainfall was $100 \mathrm{~mm}$ (no irrigation applied). Day length reduced from 12.1 hours on 23 March to 10.3 hours on 26 April.

\section{Dry matter yield and botanical composition}

The mean DM yield across all treatments was $1230 \mathrm{~kg}$ $\mathrm{DM} /$ ha (Table 2). There were no interactions between GA $\times \mathrm{N}$ or between base grass $\times \mathrm{N}$ or base grass $\times$ a).

Table 1 Pasture species and cultivars in the four pasture mixtures used in the experiment.

\begin{tabular}{|c|c|c|}
\hline \multirow[t]{2}{*}{ Species diversity } & \multicolumn{2}{|c|}{ Base Grass } \\
\hline & Perennial ryegrass & Tall Fescue \\
\hline Simple & $\begin{array}{l}\text { Diploid perennial ryegrass } \\
\text { (cv. 'One50') } \\
\text { Large Leaf White clover } \\
\text { (cv. 'Kopu II') }\end{array}$ & $\begin{array}{l}\text { Summer active tall fescue ('Advance') } \\
\text { Large Leaf White clover } \\
\text { (cv. 'Kopu II') }\end{array}$ \\
\hline Multi-species & $\begin{array}{l}\text { Diploid perennial ryegrass } \\
\text { (cv. 'One50') } \\
\text { Large Leaf White clover } \\
\text { (cv. 'Kopu II') } \\
\text { Prairie grass (cv. 'Atom') } \\
\text { Chicory (cv. 'Choice') } \\
\text { Plantain (cv. 'Tonic') } \\
\text { Red Clover (cv. 'Colenso') }\end{array}$ & $\begin{array}{l}\text { Summer active tall fescue ('Advance') } \\
\text { Large Leaf White clover } \\
\text { (cv. 'Kopu II')Prairie grass (cv. 'Atom') } \\
\text { Chicory (cv. 'Choice') } \\
\text { Plantain (cv. 'Tonic') } \\
\text { Lucerne (cv. 'Torlesse') }\end{array}$ \\
\hline
\end{tabular}


Compared with non-GA treated pasture, the application of GA increased DM yield by 31\% (1060 vs $1393 \pm 54 \mathrm{~kg} \mathrm{DM} / \mathrm{ha}, \mathrm{P}<0.05)$. Application of $\mathrm{N}$ fertiliser also increased DM yield by $14 \%$ (1308 vs 1146 $\pm 54 \mathrm{~kg} \mathrm{DM} / \mathrm{ha}, \mathrm{P}=0.05)$ which was less pronounced compared with GA.

The base grass species were more abundant in simple than MSP ( $79 \%$ vs $28 \%, \mathrm{P}<0.001)$. Perennial ryegrass was a more $(\mathrm{P}<0.05)$ abundant base pasture than tall fescue, accounting for $60 \%$ of the DM across simple and MSP compared with $45 \%$ for tall fescue. The proportion of clover ( $10 \%$ vs $4 \%$ white clover) and herb ( $43 \%$ vs $27 \%$ herb) was higher in TF-based than RG- based pastures.

In TF based simple pastures, application of GA resulted in a decrease in the proportion of white clover, whereas in all other treatments the proportion of white clover was increased by GA application (base grass $\times$ diversity $\times$ GA interaction, $\mathrm{P}<0.05$, Table 2 ). In both $\mathrm{RG}$ and TF-based pastures, the proportion of herbs increased from $31.8 \%$ to $37.9 \%$ of the $\mathrm{DM}$ when $\mathrm{N}$ fertiliser was applied $(\mathrm{P}<0.05)$. A base grass $\times$ GA interaction $(\mathrm{P}=0.013)$ showed that the proportion of herbs increased with GA in RG-based swards (23 to $31 \%$ ) but reduced with GA in TF-based swards (47\% to $39 \%$ ).

Table 2 Effect of gibberellin (GA), nitrogen $(\mathrm{N})$ or no treatment $(\mathrm{CNT})$, on mown pasture yield (kg DM/ha) and botanical composition (\% total DM) of simple and multi-species pastures sown with a base grass of ryegrass or tall fescue. SEM $=$ standard error of the mean is for the $B \times D \times G A$ interaction. $P$ values from ANOVA are shown at the base of table.

\begin{tabular}{|c|c|c|c|c|c|c|c|c|}
\hline \multirow{2}{*}{$\begin{array}{l}\text { Base pasture } \\
\text { and diversity }\end{array}$} & \multirow[t]{2}{*}{ Fertiliser } & \multirow[b]{2}{*}{ Yield } & \multicolumn{6}{|c|}{ Botanical Composition } \\
\hline & & & $\begin{array}{l}\text { Base } \\
\text { grass }\end{array}$ & $\begin{array}{l}\text { White } \\
\text { clover }\end{array}$ & Dead & $\begin{array}{r}\text { Other } \\
\text { legume }\end{array}$ & herb & $\begin{array}{r}\text { Prairie } \\
\text { grass }\end{array}$ \\
\hline \multicolumn{9}{|l|}{ Simple } \\
\hline \multirow[t]{4}{*}{ Ryegrass } & CNT & 1185 & 86.3 & 0.6 & 12.7 & - & - & - \\
\hline & GA & 1650 & 74.3 & 17.9 & 7.7 & - & - & - \\
\hline & $\mathrm{N}$ & 1583 & 76 & 1.3 & 18.1 & - & - & - \\
\hline & $\mathrm{GA}+\mathrm{N}$ & 1851 & 86.2 & 3.5 & 10.2 & - & - & - \\
\hline \multirow[t]{4}{*}{ Tall fescue } & CNT & 1089 & 72.1 & 21.8 & 6 & - & - & - \\
\hline & GA & 1338 & 78.9 & 13.3 & 5.3 & - & - & - \\
\hline & $\mathrm{N}$ & 1028 & 76 & 15.4 & 8.5 & - & - & - \\
\hline & $\mathrm{GA}+\mathrm{N}$ & 1672 & 86.4 & 9.6 & 3.8 & - & - & - \\
\hline \multicolumn{9}{|l|}{ Multi-species } \\
\hline \multirow[t]{4}{*}{ Ryegrass } & CNT & 960 & 51.6 & 0.7 & 8.3 & 5.8 & 21.8 & 11.8 \\
\hline & GA & 1108 & 31.8 & 6.3 & 4.2 & 13.3 & 29.3 & 15.2 \\
\hline & $\mathrm{N}$ & 1004 & 50.2 & 1.9 & 5.8 & 8.3 & 24.1 & 9.8 \\
\hline & $\mathrm{GA}+\mathrm{N}$ & 1280 & 42.5 & 2.7 & 5.2 & 6.4 & 32.5 & 10.7 \\
\hline \multirow[t]{5}{*}{ Tall fescue } & CNT & 804 & 15 & 3.2 & 8.6 & 6.2 & 45.7 & 21.3 \\
\hline & GA & 1036 & 13.5 & 4.1 & 9.3 & 6.9 & 30.4 & 35.5 \\
\hline & $\mathrm{N}$ & 840 & 10.8 & 6.7 & 5.5 & 8.1 & 48.1 & 20.6 \\
\hline & $\mathrm{GA}+\mathrm{N}$ & 1208 & 8.5 & 9.3 & 3.2 & 8.9 & 46.9 & 23.3 \\
\hline & SEM & 141.6 & 4.67 & 2.38 & 4.0 & 3.65 & 3.43 & 7.83 \\
\hline \multicolumn{9}{|l|}{$P$ value } \\
\hline & Base (B) & 0.23 & 0.012 & 0.008 & 0.98 & 0.8 & $<.001$ & 0.26 \\
\hline & Diversity (D) & 0.04 & $<.001$ & 0.008 & 0.97 & $N A^{*}$ & NA & NA \\
\hline & $B \times D$ & 0.60 & 0.03 & 0.09 & 0.8 & NA & NA & NA \\
\hline & GA & $<.001$ & 0.5 & 0.29 & 0.004 & 0.45 & 0.95 & 0.22 \\
\hline & $\mathrm{N}$ & 0.05 & 0.6 & 0.22 & 0.59 & 0.96 & 0.05 & 0.26 \\
\hline & $\mathrm{D} \times \mathrm{GA}$ & 0.34 & 0.02 & 0.74 & 0.07 & NA & NA & NA \\
\hline & $\mathrm{D} \times \mathrm{N}$ & 0.47 & 0.6 & 0.04 & 0.01 & NA & NA & NA \\
\hline & $B \times D \times G A$ & 0.98 & 0.71 & 0.04 & 0.25 & NA & NA & NA \\
\hline
\end{tabular}

${ }^{*} \mathrm{NA}$, not assessed as not present in mixture 


\section{Nutritive value}

Multi-species pastures had lower OM (864 vs $884 \pm$ $3.7 \mathrm{~g} / \mathrm{kg} \mathrm{DM} ; \mathrm{P}<0.01)$ and lower crude fibre (305 vs $403 \pm 11.2 \mathrm{~g} \mathrm{NDF} / \mathrm{kg}$ DM. $\mathrm{P}<0.001)$ concentration than simple pastures (Table 3). TF-based pastures had a lower concentration of ADF (206 vs $227 \pm 3.4 \mathrm{~g} \mathrm{ADF} /$ kg DM. $\mathrm{P}<0.01)$ and higher ME (11.4 vs $11.0 \pm 0.05 \mathrm{MJ}$ $\mathrm{ME} / \mathrm{kg}$ DM. $\mathrm{P}<0.01)$ than RG-based pastures.

Crude protein $(\mathrm{CP})$ concentration ranged between 157 and $233 \mathrm{~g} / \mathrm{kg}$ DM across treatments but there was no effect of base grass or diversity on crude protein concentration (193 g/kg DM, Table 3). Nitrogen fertiliser increased mean $\mathrm{CP}$ concentration from 182 to $198 \pm 3.0 \mathrm{~g} / \mathrm{kg} \mathrm{DM}(\mathrm{P}<0.01)$. A three way interaction between base grass $\times$ diversity $\times$ GA for $\mathrm{CP}$ concentration $(\mathrm{P}<0.01)$ revealed that the application of GA resulted in a $15 \mathrm{~g} \mathrm{CP} / \mathrm{kg}$ DM reduction in MSP compared with a $10 \mathrm{~g} \mathrm{CP} / \mathrm{kg}$ DM increase in simple pastures. However, in simple pastures the positive $\mathrm{CP}$ response was more pronounced in RG than TF based pastures. The variation in $\mathrm{CP}$ concentration between simple and MSP was compensated for by increased (10.2 g WSC) WSC concentration in MSP and reductions (9.2 $\mathrm{g} \mathrm{WSC}$ ) in simple pastures.

Table 3 Effect of gibberellin (GA), nitrogen (N) or no treatment (CNT), on chemical composition $(\mathrm{g} / \mathrm{kg}$ DM) and metabolisable energy content (MJ ME/kg DM) of simple and multi-species pastures sown with a base grass of ryegrass or tall fescue. $\mathrm{SEM}=$ Standard error of mean is for the $\mathrm{B} \times \mathrm{D} \times \mathrm{GA}$ interaction. $\mathrm{P}$ values from ANOVA are shown at the base of table.

\begin{tabular}{|c|c|c|c|c|c|c|c|}
\hline \multirow{2}{*}{$\begin{array}{l}\text { Base pasture } \\
\text { and diversity }\end{array}$} & \multirow[t]{2}{*}{ Fertiliser } & \multicolumn{6}{|c|}{ Chemical composition } \\
\hline & & OM & NDF & ADF & $\mathrm{CP}$ & WSC & $\mathrm{ME}$ \\
\hline \multicolumn{8}{|l|}{ Simple } \\
\hline \multirow[t]{4}{*}{ Ryegrass } & CNT & 894 & 458 & 253 & 133 & 176 & 10.7 \\
\hline & GA & 888 & 404 & 227 & 185 & 161 & 11.1 \\
\hline & $\mathrm{N}$ & 881 & 432 & 241 & 165 & 146 & 10.8 \\
\hline & $\mathrm{GA}+\mathrm{N}$ & 880 & 425 & 239 & 174 & 150 & 10.9 \\
\hline \multirow[t]{4}{*}{ Tall Fescue } & CNT & 884 & 368 & 200 & 218 & 146 & 11.5 \\
\hline & GA & 882 & 407 & 211 & 212 & 139 & 11.3 \\
\hline & $\mathrm{N}$ & 882 & 367 & 201 & 233 & 146 & 11.4 \\
\hline & $\mathrm{GA}+\mathrm{N}$ & 882 & 388 & 206 & 223 & 141 & 11.4 \\
\hline \multicolumn{8}{|l|}{ Multi-species } \\
\hline \multirow[t]{4}{*}{ Ryegrass } & CNT & 876 & 386 & 237 & 150 & 167 & 10.9 \\
\hline & GA & 876 & 359 & 234 & 160 & 158 & 10.9 \\
\hline & $\mathrm{N}$ & 863 & 296 & 203 & 205 & 142 & 11.4 \\
\hline & $\mathrm{GA}+\mathrm{N}$ & 880 & 306 & 212 & 185 & 159 & 11.0 \\
\hline \multirow[t]{5}{*}{ Tall Fescue } & CNT & 863 & 299 & 211 & 180 & 138 & 11.3 \\
\hline & GA & 869 & 317 & 215 & 186 & 138 & 11.2 \\
\hline & $\mathrm{N}$ & 861 & 279 & 195 & 219 & 133 & 11.5 \\
\hline & $\mathrm{GA}+\mathrm{N}$ & 872 & 258 & 209 & 185 & 158 & 11.3 \\
\hline & SEM & 7.26 & 17.0 & 57.7 & 10.2 & 7.14 & 0.12 \\
\hline \multicolumn{8}{|l|}{$P$ values } \\
\hline & Base (B) & 0.75 & 0.06 & 0.004 & 0.07 & 0.42 & 0.001 \\
\hline & Diversity (D) & 0.009 & $<0.001$ & 0.11 & 0.21 & 0.89 & 0.27 \\
\hline & $B \times D$ & 0.51 & 0.85 & 0.04 & 0.40 & 0.75 & 0.10 \\
\hline & GA & 0.58 & 0.61 & 0.38 & 0.77 & 0.9 & 0.36 \\
\hline & $\mathrm{N}$ & 0.5 & 0.07 & 0.06 & 0.002 & 0.38 & 0.04 \\
\hline & $\mathrm{D} \times \mathrm{GA}$ & 0.28 & 0.44 & 0.1 & $<0.001$ & 0.02 & 0.08 \\
\hline & $\mathrm{D} \times \mathrm{N}$ & 0.77 & 0.13 & 0.07 & 0.05 & 0.51 & 0.05 \\
\hline & $B \times D \times G A$ & 0.85 & 0.03 & 0.12 & 0.005 & 0.86 & 0.1 \\
\hline
\end{tabular}

OM, organic matter; NDF, neutral detergent fibre; ADF, acid detergent fibre; WSC, water-soluble carbohydrate; CP, crude protein; $\mathrm{ME}$, metabolisable energy 


\section{Discussion}

\section{Dry matter yield}

Compared with non-GA treated pastures, GA application increased DM yield in autumn by $331 \mathrm{~kg}$ $\mathrm{DM} / \mathrm{ha}(31 \%)$ when measured 4 weeks after application. These results are in line with previous studies regarding increased DM yield following GA application in autumn (Morgan \& Mees 1958; Scott 1959; Edmeades $\&$ McBride 2012). Across seasons, a wide range of DM yield increases to GA application have been reported ranging from 50 to $980 \mathrm{~kg} \mathrm{DM} / \mathrm{ha}$ for temperate grasses (Wittwer \& Bukovac 1957; Morgan \& Mees 1958; Finn \& Nielsen 1959; Scott 1959; Blacklow \& McGuire 1971; Matthew et al. 2009; McGrath \& Murphy 1976). Previous studies have demonstrated reductions in DM yield at successive harvests following GA application (Morgan \& Mees 1958; Finn \& Nielsen 1959) which is often associated with reduced tiller densities. However, no attempt was made to determine tillering behaviour or subsequent regrowth of treatments in the current study.

The results from the current study also showed increased DM yield after $\mathrm{N}$ fertiliser application, but the response was less pronounced (14\% increase) than from GA application. Previous studies have noted that relative responses to GA are greater at lower temperatures (Arnold et al. 1967; Blacklow \& McGuire. 1971) and at higher $\mathrm{N}$ fertility (Ball et al. 2012). This was confirmed in the current study, where GA applied with $\mathrm{N}$ achieved the maximum $\mathrm{DM}$ yield.

\section{Botanical composition}

The effect of GA on botanical composition was dependent on the sensitivity of the base grass to GA application relative to either herbs or legumes. In this study, base grasses were responsive to GA in simple pastures (base grass increased by $450 \pm 121 \mathrm{~kg} \mathrm{DM} / \mathrm{ha}$ ) but not in MSP (base grass decreased by $36 \pm 59 \mathrm{~kg} \mathrm{DM} /$ ha). A range of grass species have been shown to respond positively to GA (Wittwer \& Bukovac 1957; Finn \& Neilson 1959; Laude et al. 1960), although the relative response tends to be greater in tall fescue than ryegrass (Wittwer \& Bukovac 1957). This was demonstrated in the current study by the clover response in RG and TF simple pastures. A strong response to GA by tall fescue resulted in a reduction in white clover content in TF pastures while a moderate response to GA by ryegrass resulted in an increase in white clover in RG pastures. In a comparison of grasses and legumes responding to different GA rates, Finn \& Nielson (1959) showed that legumes were more responsive to GA than grasses, particularly at very high rates of GA (295 to $590 \mathrm{~g} / \mathrm{ha}$ ). On the other hand, herbs did not respond to GA (herbs increased by $66 \pm 77 \mathrm{~kg} \mathrm{DM} / \mathrm{ha}$ ) but accounted for a higher proportion in the pasture when $\mathrm{N}$ was applied (herbs increased by $180 \pm 74 \mathrm{~kg} \mathrm{DM} / \mathrm{ha}$ ). Chicory and plantain showed a positive response to GA application in previous studies (Wittwer \& Bukovac 1957; Dijkstra et al. 1990) but these results were in spring when the plant became reproductive. The evidence from this and previous studies show that botanical changes and yield of pastures after GA application will be influenced by the abundance of the most responsive plant species when GA is applied. The size of the response then is subject to season (particularly in the case of herbs), $\mathrm{N}$ fertility and climatic conditions.

\section{Nutritive value}

Metabolisable energy was higher in TF based than RG based pastures (11.3 vs. $10.9 \pm 0.05 \mathrm{MJME} / \mathrm{kg} \mathrm{DM}$ ), which may be accounted for by the high content of clover. There was little effect of GA on ME; this reflects that GA application did not alter ADF concentration from which ME was calculated (CSIRO 2007).

The effect of GA on CP concentration of simple and MSP also appeared to be linked to changes in the clover content of the pastures. In MSP, where the clover content was low $(<10 \%)$ and increased only marginally due to GA application, the concentration of CP was reduced with GA application irrespective of the base grass. In simple pastures, there was a reduction in the $\mathrm{CP}$ concentration of TF based pastures because white clover content decreased; in contrast, in simple RG based pastures, white clover content increased from $1 \%$ to $11 \%$ due to $\mathrm{GA}$, therefore increasing overall crude protein concentration. Reductions in crude protein following GA application have been shown in some cases (Finn \& Nielsen 1959; Brown et al. 1963), but not all (Morgan \& Mees 1958; Matthew et al. 2009; Parsons et al. 2013). In MSP it is difficult to attribute change in the $\mathrm{CP}$ to one particular species but increased overall DM yield without appreciable change in legume content has in this case reduced $\mathrm{CP}$ concentration.

\section{Summary}

A single GA application to conventional grass and clover pastures offers an opportunity to improve DM production in autumn. Responses of pastures containing a high proportion of herbs may not achieve the same yield benefits as grass/clover pastures. However, from an environmental standpoint, autumn is a critical period in which $\mathrm{N}$ leaching losses from urine patches are high and amenable to manipulation by reducing the $\mathrm{CP}$ concentration of the diet. Provided there is sufficient $\mathrm{CP}$ in the diet to meet animal requirements the reduction in $\mathrm{CP}$ concentration in both simple and multi-species pastures following GA application offers an opportunity to reduce $\mathrm{N}$ losses. 


\section{ACKNOWLEDGEMENTS}

Thanks to Jeff Curtis, Melanie Miller, Winy van Rossum, Robert Trott, Kendal Bruce, Alice Speedy and Andrew Goodger who assisted with fieldwork.

\section{REFERENCES}

Arnold, G.W.; Bennett, D.; Williams, C.N. 1967. The promotion of winter growth in pastures through growth substances and photoperiod. Crop and Pasture Science 18: 245-257.

Ball, C.C.; Parsons, A.J.; Rasmussen, S.; Shaw C.; Rowarth, J.S. 2012. Seasonal differences in the capacity of perennial ryegrass to respond to gibberellin explained. Proceedings of the New Zealand Grassland Association 74: 183-187.

Blacklow, W.M.; McGuire, W.S. 1971. Influence of gibberellic acid on the winter growth of varieties of tall fescue (Festuca arundinacea Schreb.). Crop Science 11: 19-22.

Brown, R.H.; Blaser, R.E.; Fontenot, J.P. 1963. Digestibility of grasses treated with gibberellic acid. Journal of Animal Science 22: 1038-1042.

CSIRO 2007. Nutrient requirements of domesticated ruminants. CSIRO Publishing, Collingwood, VIC. Australia. p 9.

De Klein, C.A.M. 2001. An analysis of environmental and economic implications of nil and restricted grazing systems designed to reduce nitrate leaching from New Zealand dairy farms. II. Pasture production and cost/benefit analysis. New Zealand Journal of Agricultural Research 44: 217-235.

Di, H.J.; Cameron, K.C. 2002. Nitrate leaching in temperate agroecosystems: sources, factors and mitigating strategies. Nutrient Cycling in Agroecosystems 64: 237-256.

Dijkstra, P.; Reegen, H.; Kuiper, P.J.C. 1990. Relation between relative growth rate, endogenous gibberellins, and the response to applied gibberellic acid for Plantago major. Physiologia Plantarum 79: 629-634.
Edmeades, D.C.; McBride, R.M. 2012. Evaluating the agronomic effectiveness of fertiliser products. New Zealand Grassland Association 74: 217-224.

Finn, B.J.; Nielsen, K.F. 1959. Effects of gibberellin on forage yields of six grass and legume species. Canadian Journal of Plant Science 39: 175-182.

Laude, H.M.; Jones, M.B.; Winans, S.S. 1960. Responses of annual range to gibberellic acid. Journal of Range Management 13:10-13.

Matthew, C.; Hofmann, W.A.; Osborne, M.A. 2009. Pasture response to gibberellins: a review and recommendations. New Zealand Journal of Agricultural Research 52: 213-225.

McGrath, D.; Murphy, P. 1976. Promotion of early grass growth using gibberellic acid. Irish Journal of Agricultural Research 15: 257-263.

Morgan, D.G.; Mees, G.C. 1958. Gibberellic acid and the growth of crop plants. Journal of Agricultural Science Cambridge 50: 49-59.

Nobilly, F.; Bryant, R.H.; McKenzie, B.A.; Edwards, G.R. 2013. Productivity of rotationally grazed simple and diverse pasture mixtures under irrigation in Canterbury. Proceedings of the New Zealand Grassland Association 75: 165-171.

Parsons, A.J.; Rasmussen, S.; Liu, Q.; Xue, H.; Ball, C.; Shaw, C. 2013. Plant growth - resource or strategy limited: insights from responses to gibberellin. Grass and Forage Science doi:10.1111/gfs.12035

Scott, R.S. 1959. Effect of gibberellic acid and nitrogen on winter growth of pasture. New Zealand Journal Agricultural Research 2: 1203-1210.

Totty, V.K.; Greenwood, S.L.; Bryant, R.H.; Edwards, G.R. 2013. Nitrogen partitioning and milk production of dairy cows grazing simple and diverse pastures. Journal of Dairy Science 96: 141-149.

Wittwer, S.H.; Bukovac, M.J. 1957. Gibberellin and higher plants. V. Promotion of growth in grass at low temperatures. Quarterly Bulletin of the Michigan University Agricultural Experimental Station 39: 682-686. 